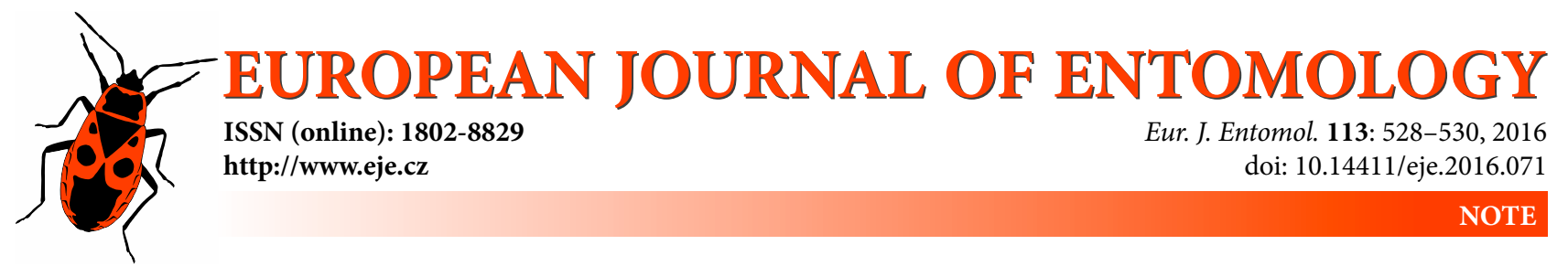

\title{
Isolation and characterization of novel microsatellite loci in the genome of the dragonhead sap beetle Thymogethes norvegicus (Coleoptera: Nitidulidae)
}

\author{
Oddmund KLEVEN ${ }^{1}$ and Anders ENDREST $\varnothing^{2}{ }^{2}$ \\ ${ }^{1}$ Norwegian Institute for Nature Research (NINA), Høgskoleringen 9, NO-7034 Trondheim, Norway; \\ e-mail: oddmund.kleven@nina.no \\ ${ }^{2}$ Norwegian Institute for Nature Research (NINA), Gaustadalléen 21, NO-0349 Oslo, Norway; \\ e-mail: anders.endrestol@nina.no
}

Key words. Coleoptera, Nitidulidae, Thymogethes norvegicus, microsatellite loci, genetic diversity

\begin{abstract}
Here we describe 16 novel microsatellite loci in the genome of the dragonhead sap beetle Thymogethes norvegicus, which were identified using a next-generation sequencing approach. In 40 dragonhead sap beetles from a population in southern Norway, we found 2-4 alleles per locus. Expected heterozygosity ranged from 0.18-0.65. Three of the loci showed significant deviation from Hardy-Weinberg equilibrium. After correcting for multiple tests, one pairwise locus combination displayed significant linkage disequilibrium. These novel microsatellite loci will be useful for future population structure, genetic diversity and conservation genetic studies of the dragonhead sap beetle.
\end{abstract}

\section{INTRODUCTION}

The dragonhead sap beetle Thymogethes norvegicus (Easton 1959), belonging to the Nitidulidae, was until recently assigned to the genus Meligethes Stephens, 1830 (Audisio et al. 2009). Easton (1959) described this species based on a series of individuals collected in southern Norway on the northern dragonhead Dracocephalum ruyschiana, which later was identified as its host plant (Stabbetorp \& Endrestøl, 2011). Up to the year 2000, the global distribution of the dragonhead sap beetle was restricted to coastal areas in the Bærum municipality in Norway. In recent years, however, the species has been found in neighbouring municipalities (Stabbetorp \& Endrestøl, 2011). Despite searching for it in other countries where it may occur (A. Endrestøl, unpubl. data), the dragonhead sap beetle is currently considered endemic to Norway (Stabbetorp \& Endrestøl, 2011) and listed as endangered (EN) on the Norwegian Red List (Henriksen \& Hilmo, 2015). In order to estimate the connectivity and genetic structure among populations of the dragonhead sap beetle we used high-throughput sequencing to identify novel microsatellite loci in the genome of this species.

\section{MATERIAL AND METHODS}

Seven dragonhead sap beetles collected in June 2015 in southern Norway (Latitude: 59.89947843, Longitude: 10.60829173) was sent to Ecogenics $\mathrm{GmbH}$ (Balgach, Switzerland) to produce an enriched microsatellite library and test for marker polymorphism. In brief, DNA was extracted from the beetles using a manual commercial kit (DNeasy Blood and Tissue Kit; Qiagen, Hilden, Germany) following the manufacturers protocol. Sizeselected fragments of genomic DNA were enriched for simple sequence repeats (SSRs) by using streptavidin-coated magnetic beads and biotin-labelled GTAT and GATA repeat oligonucleotides. The SSR-enriched library was analyzed on an Illumina MiSeq (Illumina, San Diego, CA, USA) platform at Microsynth AG (Balgach, Switzerland) using the Nano $2 \times 250$ v2 format. The resulting 335001 sequences were stitched, assembled and candidate microsatellites were searched for in the assembled 21390 contigs at Ecogenics using an in-house script. After assembly, 770 contigs or singlets contained a microsatellite insert with a tetra- or a trinucleotide of at least six repeat units or a dinucleotide of at least ten repeat units. Primer3 (Rozen \& Skaletsky, 2000) was used to design PCR primers for 439 microsatellite candidates. Of the 439 microsatellite candidates, 36 were tested for polymorphism. Then, a selection based on genetic variation, single polymerase-chain reaction (PCR) performance and peak interpretation was performed.

Microsatellite loci were PCR amplified with fluorescently labelled (6FAM) forward primers. PCRs were performed in a final volume of $8.4 \mu \mathrm{L}$ and the protocol consisted of $95^{\circ} \mathrm{C}$ for $15 \mathrm{~min}$, 30 cycles of $95^{\circ} \mathrm{C}$ for $30 \mathrm{~s}, 56^{\circ} \mathrm{C}$ for $90 \mathrm{~s}, 72^{\circ} \mathrm{C}$ for $60 \mathrm{~s}$ and a final extension step of $60^{\circ} \mathrm{C}$ for 30 minutes. PCR products $(0.8 \mu \mathrm{L})$ were mixed with Genescan 500 LIZ (Applied Biosystems, Foster City, CA, USA) size standard $(0.14 \mu \mathrm{L})$ and Hi-Di formamide $(6.16 \mu \mathrm{L})$. Alleles were separated using capillary electrophoresis on an ABI 3130xl Genetic Analyzer and sizes assigned using Genemapper software (Applied Biosystems).

For genotyping, we used DNA from 40 individuals, all collected in the years 2009-2015 in the Oslofjord area in southern Norway. Genomic DNA was extracted from a leg or whole speci- 
Table 1. Characterization of 16 novel microsatellite loci in the genome of Thymogethes norvegicus.

\begin{tabular}{|c|c|c|c|c|c|c|c|c|c|c|c|c|}
\hline Locus & Clone & Primer sequences $\left(5^{\prime}-3^{\prime}\right)$ & $\begin{array}{c}\text { Primer } \\
\text { Tm } \\
\left({ }^{\circ} \mathrm{C}\right)\end{array}$ & $\begin{array}{c}\text { Repeat } \\
\text { motif }\end{array}$ & $n$ & A & $H_{\mathrm{O}} \quad H_{\mathrm{E}}$ & $\begin{array}{l}\text { Expected } \\
\text { allele size } \\
\text { (bp) }\end{array}$ & $\begin{array}{l}\text { Observed } \\
\text { e allele size } \\
\text { range (bp) }\end{array}$ & $P_{\mathrm{HWE}}$ & $F_{\text {NULL }}$ & $\begin{array}{l}\text { GenBank } \\
\text { no. }\end{array}$ \\
\hline Tno01 & Melnor_00389s & $\begin{array}{l}\text { F: ATGTAGCCCGCTTTGTTTCC } \\
\text { R: TCACAGTCACTATCACCACAC }\end{array}$ & $\begin{array}{l}61 \\
54\end{array}$ & $(\mathrm{TACA})_{8}$ & 40 & 2 & 0.250 .32 & 223 & $210-222$ & 0.16 & 0.05 & KX831620 \\
\hline Tno02 & Melnor_00574s & $\begin{array}{l}\text { F: CGAGAAAATTAACCCAATGAGATAGC } \\
\text { R: GGAGGACTGGATCAAAACAGC }\end{array}$ & $\begin{array}{l}62 \\
61\end{array}$ & $(\mathrm{ACAA})_{12}$ & 40 & 3 & 0.400 .39 & 188 & $64-188$ & 0.88 & 0 & X831621 \\
\hline Tno03 & Melnor_00735s & $\begin{array}{l}\text { F: GGGTCCCCATATCAGCTTCC } \\
\text { R: TAAACATGTCCCCCGTCTCC }\end{array}$ & $\begin{array}{l}63 \\
62\end{array}$ & $(\mathrm{TCTA})_{7}$ & 40 & 3 & 0.330 .47 & 165 & $158-170$ & 0.02 & 0.10 & 1622 \\
\hline Tno04 & Melnor_00857s & $\begin{array}{l}\text { F: GCACAATAAAC } \\
\text { R: TTGGTTCACCG }\end{array}$ & $\begin{array}{l}63 \\
63\end{array}$ & $(\text { ATAC })_{8}$ & 40 & 2 & 0.480 .45 & 211 & 210-218 & 1.00 & 0 & 623 \\
\hline Tno05 & Melnor_01015s & $\begin{array}{l}\text { F: GCTAC } \\
\text { R: AGTGA }\end{array}$ & $\begin{array}{l}59 \\
62\end{array}$ & $(\mathrm{GTAT})_{8}$ & 40 & 3 & 50.62 & 0 & 50 & 0.58 & 0.04 & 24 \\
\hline Tno06 & Melnor_01 & $\begin{array}{l}\text { F: TCCATC } \\
\text { R: TTGCT }\end{array}$ & $\begin{array}{l}57 \\
62\end{array}$ & $(\mathrm{CAAA})_{7}$ & 40 & 2 & 0.100 .18 & 8 & 45 & 0.03 & 0.07 & 25 \\
\hline Tno07 & Melnor_01260s & $\begin{array}{l}\text { F: AAATAT } \\
\text { R: GAGTTC }\end{array}$ & $\begin{array}{l}59 \\
63\end{array}$ & $(\text { TGTA })_{8}$ & 40 & 2 & 0.530 .50 & 142 & 140 & 0.76 & 0 & 626 \\
\hline Tno08 & Melnor_01 & $\begin{array}{l}\text { ACATAG } \\
\text { CCAAAAATG }\end{array}$ & $\begin{array}{l}62 \\
61\end{array}$ & $(\text { ATAG })_{14}$ & 40 & 4 & 0.55 & 160 & 171 & 0.25 & 0.03 & 627 \\
\hline Tno09 & Melnor_02057s & $\begin{array}{l}\text { F: TCATGGCTTGGAAAATGCAG } \\
\text { R: TCCTTTTTGTGGATCTTTTTGGAAC }\end{array}$ & $\begin{array}{l}62 \\
64\end{array}$ & $(T A G A)_{8}$ & 40 & 2 & 0.330 .31 & 190 & 188 & 1.00 & 0 & 628 \\
\hline Tno10 & Melnor_02892s & $\begin{array}{l}\text { F: AAAAAGC } \\
\text { R: GAAGTAG }\end{array}$ & $\begin{array}{l}60 \\
58\end{array}$ & $(\mathrm{CATA})_{8}$ & 40 & 2 & 0.280 .31 & 165 & 63 & 0.60 & 0.02 & 29 \\
\hline Tno11 & Melnor_03264s & $\begin{array}{l}\text { F: CAGCTTCACCTTTTCCCTGC } \\
\text { R: GTTTTTGAGCGACCTCTCTGG }\end{array}$ & $\begin{array}{l}62 \\
61\end{array}$ & $(\mathrm{TAGA})_{12}$ & 40 & 3 & 0.350 .44 & 203 & 199 & 0.02 & 0.06 & 630 \\
\hline Tno12 & Melnor_05317s & $\begin{array}{l}\text { F: CGACCGTTCGATTCTTTCGC } \\
\text { R: TGCCTTTTCATTGGGTGCTG }\end{array}$ & $\begin{array}{l}65 \\
64\end{array}$ & $(\mathrm{CAAA})_{7}$ & 40 & 3 & 0.380 .32 & 244 & 233-241 & 0.75 & 0 & 631 \\
\hline Tno13 & Melnor_07176s & $\begin{array}{l}\text { F: GCTCGTGTAACCTGACTTGC } \\
\text { R: GAATACAGCATATTCCGCTCG }\end{array}$ & $\begin{array}{l}59 \\
60\end{array}$ & $(\text { TATC })_{15}$ & 40 & 3 & 0.550 .59 & 159 & -159 & 0.49 & 0.02 & 632 \\
\hline Tno14 & Melnor_09908s & $\begin{array}{l}\text { F: TGGAGGAGAACCTAAAGGCG } \\
\text { R: AGAAGTAGTTGAAAAAGCTGTCG }\end{array}$ & $\begin{array}{l}62 \\
57\end{array}$ & $(\mathrm{TTTG})_{7}$ & 40 & 2 & 0.450 .47 & 245 & -243 & 0.75 & 0.01 & KX831633 \\
\hline Tno15 & Melnor_14604s & $\begin{array}{l}\text { F: AGACTAACGCACAGCAATTC } \\
\text { R: GCTTTGACCACTTACCTGGG }\end{array}$ & $\begin{array}{l}56 \\
60\end{array}$ & $(\mathrm{AGAT})_{13}$ & 40 & 4 & 0.680 .65 & 97 & $70-102$ & 1.00 & 0 & KX831634 \\
\hline Tno16 & Melnor_20171s & $\begin{array}{l}\mathrm{F}: \text { GTGATGGGCGCATTGTCTAC } \\
\text { R: TGCTATATCCATTTAGAGCCGTC }\end{array}$ & $\begin{array}{l}61 \\
60\end{array}$ & $(\mathrm{AGAT})_{10}$ & 40 & 3 & 0.280 .28 & 161 & $152-160$ & 0.68 & 0 & KX831635 \\
\hline
\end{tabular}

Tm - melting temperature; $\mathrm{n}$ - number of individuals genotyped; A - number of alleles observed; $H_{\mathrm{O}}-$ observed heterozygosity; $H_{\mathrm{E}}-$ expected heterozygosity; $P_{\mathrm{HWE}}-P$-value for test for deviation from Hardy-Weinberg equilibrium; $F_{\mathrm{NULL}}-$ estimated frequency of null-alleles according to the Brookfield 2 method implemented in Micro-Checker (van Oosterhout et al., 2004).

mens using a manual commercial kit (Qiagen DNeasy blood and tissue kit) following the manufacturer's protocol.

The mean number of alleles, observed and expected heterozygosities, deviation from Hardy-Weinberg equilibrium and linkage disequilibrium were estimated using Arlequin version 3.5.1.2 (Excoffier \& Lischer, 2010). A Bonferroni correction for multiple statistical tests (Rice, 1989) was applied to linkage disequilibrium $P$-values. Null-allele frequencies were estimated using MicroChecker version 2.2.3 (van Oosterhout et al., 2004).

\section{RESULTS AND DISCUSSION}

PCR analysis of seven individuals was done for the 36 microsatellite loci. Of these 36 loci, 16 were polymorphic, twelve were monomorphic, five were difficult to interpret and for three there were more than two alleles per individual. There were 2.7 alleles per locus (range 2 to 4 ; Table 1 ) at the 16 polymorphic loci in 40 beetles. The mean expected heterozygosity was 0.43 (range 0.18 to 0.65 ) and mean observed heterozygosity was 0.40 (range 0.10 to 0.68; Table 1). Evidence for null-alleles was recorded at one locus (Tno03) and three loci (Tno03, Tno06 and Tno11) deviated significantly from Hardy-Weinberg equilibrium (Table 1). After correcting for multiple tests, one locus pair (Tno03 and Tno15) displayed significant linkage disequilibrium. In conclusion, these novel microsatellite loci will be useful for future genetic analyses of the dragonhead sap beetle.
ACKNOWLEDGEMENTS. We are grateful to H. Elven at the Natural History Museum in Oslo for providing the additional larval specimen used in this analysis, and two reviewers for providing valuable comments. This study was conducted as part of the research project "Management of biodiversity and ecosystem services in spatially structured landscapes" (208434/F40) and financed by the Research Council of Norway.

\section{REFERENCES}

Audisio P., Cline A.R., De Biase A., Antonini G., Mancini E., Trizzino M., Costantini L., Strika S., Lamanna F. \& Cerretti P. 2009: Preliminary re-examination of genus-level taxonomy of the pollen beetle subfamily Meligethinae (Coleoptera: Nitidulidae). - Acta Entomol. Mus. Nat. Pragae 49: 341-504.

EAston A. 1959: A new Norwegian species of Meligethes Stephens (Col., Nitidulidae). — Norw. J. Entomol. 11: 50-53.

Excoffier L. \& Lischer H.E.L. 2010: Arlequin suite ver 3.5: a new series of programs to perform population genetics analyses under Linux and Windows. - Mol. Ecol. Res. 10: 564-567.

Henriksen S. \& Hilmo O. (eds) 2015: The 2015 Norwegian Red List for Species. Norwegian Biodiversity Information Centre, Trondheim, $193 \mathrm{pp}$.

Rice W.R. 1989: Analyzing tables of statistical tests. - Evolution 43: $223-225$.

Rozen S. \& Skaletsky H.J. 2000: Primer3 on the WWW for general users and for biologist programmers. In Krawetz S. 
\& Kisener S. (eds): Bioinformatics Methods and Protocols: Methods in Molecular Biology. Humana Press, Totawa, NJ, pp. 365-386.

Stabbetorp O.E. \& Endrestøl A. 2011: Scientific Basis for Action Plan for the Northern Dragonhead Dracocephalum ruyschiana and the Northern Dragonhead Sap Beetle Meligethes norvegicus. NINA Report 766. Norwegian Institute for Nature Research, Trondheim, $61 \mathrm{pp}$. van Oosterhout C., Hutchinson W.F., Wills D.P.M. \& Shipley P. 2004: MICRO-CHECKER: software for identifying and correcting genotyping errors in microsatellite data. - Mol. Ecol. Notes 4: 535-538.

Received September 12, 2016; revised and accepted October 19, 2016 Published online October 31, 2016 